\title{
Ataxia due to vertebral hemangiosarcoma with evidence of disseminated disease in a 20 -year old Swiss Warmblood mare
}

\author{
Lucia Unger', Christine Goepfert', Fanny Berruex? ${ }^{2}$ Daniela Gorgas ${ }^{3}$, Vinzenz Gerber ${ }^{7}$ and Horst Posthaus ${ }^{2}$ \\ Division of Clinical Veterinary Medicine, Equine Clinic of the Suisse Institute for Equine Medicine ${ }^{1}$, Institute of Animal Pathology and Division of Clinical Radio- \\ logy, Department of Clinical Veterinary Medicine ${ }^{3}$, Vetsuisse Faculty, University of Bern, Bern, Switzerland
}

\begin{abstract}
Summary
A 20-year old Swiss Warmblood mare was referred to the Swiss Institute of Equine Medicine with a history of poor performance, coughing and ataxia and hindlimb weakness which progressed to recumbency. Lung auscultation revealed pronounced wheezing, blood work showed signs of chronic inflammation and increased bone turnover and thoracic ultrasound indicated patchy pulmonary consolidation. Cerebrospinal fluid revealed only mild, unspecific changes allowing exclusion of meningoencephalomyelitis and clinically relevant bleeding. Despite medical treatment and support in a sling the mare did not improve and was euthanized. Necropsy revealed a poorly demarcated, non-encapsulated and invasively growing mass dorsally in the musculature at the level of the forth cervical vertebra (C4) infiltrating the vertebral body and the spinal canal at the level of $\mathrm{C} 1-\mathrm{C} 2$. Multiple nodular, firm masses were present in all lobes of the lung and appeared to be mainly located in vessels. Histologically the masses were composed of spindle cells with marked anisocytosis, anisocaryosis, a high mitotic activity and showed invasive growth. These neoplastic cells stained positive for CD31, an endothelial cell marker, which confirmed diagnosis of a hemangiosarcoma. Definite ante mortem diagnosis of hemangiosarcoma, which is rare in horses, is challenging. Besides the vertebral localization, disseminated, locally invasive and cutaneous forms of hemangiosarcoma exist and can be either acquired or congenital. Prognosis for equine hemangiosarcoma and response to treatment are usually poor and progression of clinical signs is rapid. Vertebral hemangiosarcoma is an uncommon cause of spinal ataxia in horses.
\end{abstract}

Keywords: neoplasia / hemangiosarcoma / vertebral / horse / spinal ataxia / metastasis

\begin{abstract}
Ataxie aufgrund eines vertebralen Hämangiosarkoms mit Metastasierung bei einer 20-jährigen Schweizer Warmblutstute
Eine 20-jährige Schweizer Warmblutstute mit einer Vorgeschichte von Husten und Leistungsschwäche wurde wegen akuter Ataxie und Hinterhandschwäche festliegend eingeliefert. Über der Lunge war lautes Giemen auskultierbar, eine Blutuntersuchung zeigte Anzeichen einer chronischen Entzündung sowie eines erhöhten Knochenstoffwechsels, und im Lungenultraschall waren multiple, oberflächliche, konsolidierte Bereiche sichtbar. Der Liquor cerebrospinalis war nur leichtgradig entzündlich verändert, was den Ausschluss einer Meningoencephalomyelitis oder einer klinisch bedeutsamen Blutung erlaubte. Trotz eines intensiven medikamentellen Therapieversuchs inklusive Aufhängung in einem Netz verbesserte sich der Zustand der Stute nicht und sie musste euthanasiert werden. Bei der Sektion wurde in der Muskulatur dorsal des vierten Halswirbels (C4) eine den Wirbel, den Wirbelkanal und in Höhe des 1. / 2. Halswirbels auch das Rückenmark infiltrierende, schlecht begrenzte Masse gefunden. In allen Lungenlappen wurden multiple derbe, teils mit den Gefässen assoziierte Massen vorgefunden. Histologisch waren die Massen in Halsmuskulatur, Halswirbeln, Wirbelkanal und Rückenmark aus Spindelzellen mit deutlicher Anisozytose, Anisokaryose und hoher Mitoserate zusammengesetzt und zeigten invasives Wachstum. Sie färbten sich immunohistochemisch positiv für CD31, einen Endothelzellmarker, an, was die Diagnose eines Hämangiosarkoms bestätigte. Eine definitive ante mortem Diagnose kann beim Hämangiosarkom, einer beim Pferd seltenen Erkrankung, meist nicht gestellt werden. Neben der vertebralen Lokalisation existieren disseminierte, lokal invasive und kutane Formen des Hämangiosarkoms, die entweder erworben oder angeboren sein können. Die Prognose für ein equines Hämangiosarkom und das Ansprechen auf Therapie sind gewöhnlich schlecht und das Voranschreiten der klinischen Symptome schnell. Das vertebrale Hämangiosarkom ist eine äusserst seltene Ursache für spinale Ataxie beim Pferd.
\end{abstract}

Schlüsselwörter: Neoplasie / Hämangiosarkom / vertebral / Pferd / spinale Ataxie / Metastasierung

\section{Case history}

Clinical findings

A 20-year old Swiss Warmblood mare was referred to the Swiss Institute of Equine Medicine with a history of poor performance and coughing of two months duration and ataxia and hindlimb weakness of acute onset. The ataxia, mainly accentuated in the hindlimbs, was first recognized by the private veterinarian three days before arrival in the clinic, and had progressed to recumbency during the two hour transport in the trailer. At arrival in the clinic, the mare was in lateral recumbency and unable to rise on her own. Her heart and respiratory frequency were elevated (52/min resp. $28 / \mathrm{min})$, her mucus membranes congested and capillary refill time was slightly prolonged ( 3 seconds). Auscultation of the lung revealed pronounced wheezing. The mare showed a normal mental status and had no cranial nerve deficits. The hindlimbs were paretic. There were no signs of muscle atrophy or sensory loss, but spastic movements were observed. Thoracic limbs were less severely affected: voluntary movement, muscle tone and cutaneous sensation were normal, but mild spasticity of movement was also noted in the frontlimbs. Anal tone and sphincter reflexes were normal. The mare did not show any signs of urinary or fecal incontinence. Based on these findings, upper motor neuron damage localized in the cervical spinal cord $(\mathrm{Cl}-\mathrm{C} 5)$ was suspected. 


\section{Diagnostic workup}

Blood work revealed a marked leukocytosis (leucocytes $42,78 \times 10^{9} / 1$, reference range $5,3-10,3 \times 10^{9} /$ ) with distinct neutrophilia $\left(39,79 \times 10^{9} /\right.$, reference range 2,5-6,0 × 10\%/I), moderately increased AP (521 U/l, reference range $0-227 \mathrm{U} / \mathrm{I}$ ) and slightly elevated muscle enzyme activities (CK $696 \mathrm{U} /$, reference range 0-268 U/I, LDH $994 \mathrm{U} / \mathrm{I}$, reference range 10-839 U/I). Hematological changes were unspecific and more compatible with chronic inflammation than acute infectious disease. The total serum activity of alkaline phosphatase is composed of several isoenzymes, of which the liver, bone and intestinal isoforms predominate. Since the liver specific cytosolic enzymes, namely $\mathrm{SDH}(2 \mathrm{U} / \mathrm{l}$, reference range $0-7 \mathrm{U} / \mathrm{I})$ and $\mathrm{GLDH}$ $(<1 \mathrm{U} / \mathrm{l}$, reference range $0-14 \mathrm{U} / \mathrm{l})$, were within normal range and there were no clinical or anamnestic data indicative of intestinal disease, the moderately elevated AP was suspected to be caused by increased bone metabolism. The mild elevation of muscle enzymes was thought to be due to the prolonged recumbency. Since the mare was unable to stand and walk, she was sedated with romifidine $(0.04$ $\mathrm{mg} / \mathrm{kg}$ bwt IV) and butorphanol (0.05 mg/kg bwt IV), induced with ketamine $(2.2 \mathrm{mg} / \mathrm{kg}$ bwt IV) and diazepam (0.1 $\mathrm{mg} / \mathrm{kg}$ bwt IV) and transported under general anesthesia in a sling into a padded stall. A cerebrospinal fluid aspirate, obtained under general anesthesia in the atlantooccipital space, revealed a slightly increased leucocyte count $(12,7 / \mu \mathrm{l}$, reference range $<10 / \mu \mathrm{l}$ ) (Andrews 2010) with mildly increased neutrophils (15\%), normal total protein concentration $(0,68 \mathrm{~g} / \mathrm{l}$, reference range $0,28-0,77 \mathrm{~g} / \mathrm{l})$, presence of erythrocytes and a positive Pandy test. Neither infectious organisms nor tumor cells were identified. Finding red blood cells in the cerebrospinal fluid may be a sign of bleeding. However, the few red blood cells in the tap may also be due to puncturing a blood vessel with the spinal tap needle while entering the skin or dura. The latter is most likely cause in the present case since the leucocyte count was also mildly elevated. Septic or non-septic meningoencephalomyelitis is expected to result in more marked inflammatory changes and was therefore excluded. Despite absence of neoplastic cells a tumor could not be excluded. Tumor cells may only be present in the cerebrospinal fluid if the tumor itself is exfoliative and in contact to the subarachnoid space. The Pandy reaction, a semiquantitative and very sensitive method to detect elevated levels of protein, chiefly globulins, was mildly positive. In the face of normal total protein levels, this might be a sign of mildly increased permeability of the blood brain barrier, an unspecific finding present in a variety of central nervous system disorders.

After recovery from anesthesia a thoracic ultrasound was performed due to the persistent, increased respiratory effort and rate. The pulmonary surface was irregular with patchy, consolidated, round areas with a maximal diameter of $2-3 \mathrm{~cm}$ (Figure 1A - C). An ultrasonographic scan of the abdominal organs did not reveal any abnormality.

\section{Clinical course}

Based on the suspicion of an acute compressive lesion with edema formation in the spinal cord and after exclusion of significant hemorrhage into the cerebrospinal fluid an antiinflammatory therapy (dexamethasone $0.2 \mathrm{mg} / \mathrm{kg}$ bwt IV) and treatment with hyperosmolar agents were initiated (mannitol $25 \%, 1 \mathrm{~g} / \mathrm{kg}$ bwt IV, and hypertonic $\mathrm{NaCl} 7.2 \%, 4 \mathrm{ml} / \mathrm{kg}$ bwt IV, followed by isotonic crystalloid fluids, $30 \mathrm{ml} / \mathrm{kg}$ bwt IV). Even though meningitis was excluded, the multiple severe pulmonary lesions warranted broad spectrum antibiotics (penicillin $30000 \mathrm{lU} / \mathrm{kg}$ bwt IV, gentamicin $6.5 \mathrm{mg} / \mathrm{kg}$ bwt IV). In the padded stall, the mare remained in the sling, but several attempts to assist her to stand by lifting her in the sling were unsuccessful.

Our primary findings based on physical examination findings, blood work, analysis of cerebrospinal fluid and thoracic and abdominal ultrasound were cervical spinal cord injury, patchy pulmonary consolidation and signs of increased bone turnover. Since the central nervous system, the musculoskeletal and the respiratory systems were all affected and blood work revealed evidence of chronic inflammation, a disseminated disease process, specifically neoplasia with metastasis, was considered as the primary differential.

Despite treatment the general condition of the mare did not improve over the next four hours. Because of the guarded to poor prognosis the owner declined the options of further diagnostic workup including radiographs, myelography and magnet resonance imaging of the neck and biopsies of the

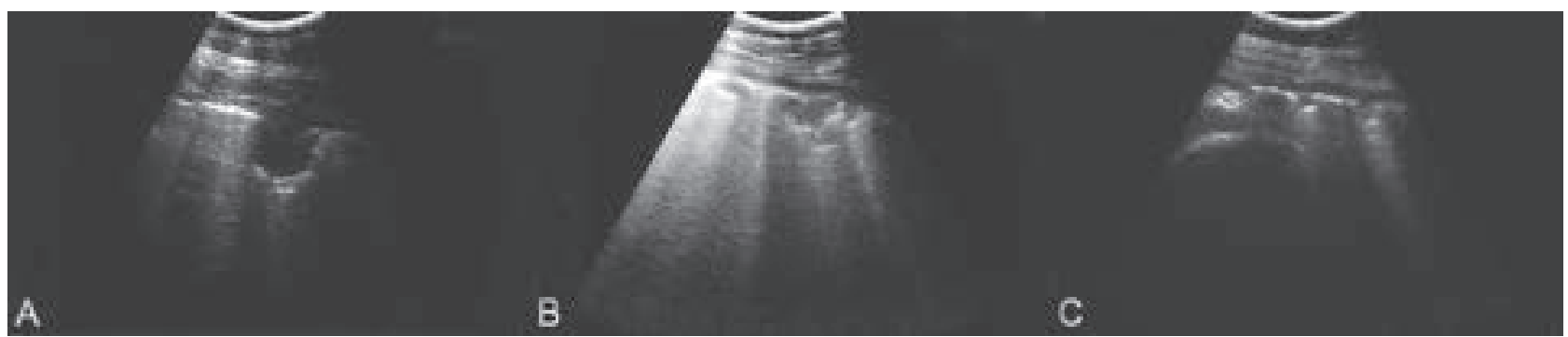

Fig. 1 Sonograms of the thorax obtained in the right and left 3rd-16th intercostal space. Dorsal is to the right and ventral is to the left. (A) Sonogram of a round, superficial, hypoechoic, consolidated area with a diameter of $26.1 \mathrm{~mm}$ obtained in the right 8th intercostal space. (B) Sonogram of comet tail artifacts and a small oval, consolidated, hypoechoic area obtained in the left 10th intercostal space. (C) Sonogram of the ventral lung in the right 10th intercostal space. Notice the irregular pleural surface with comet tail artifacts.

Ultraschallbilder des Thorax vom rechten und linken 3.-16. Interkostalraum. Dorsal ist rechts, ventral ist links. (A) Ultraschall eines runden, oberflächlichen, hypoechogenen Bereichs mit einem Durchmesser von $26.1 \mathrm{~mm}$ im 8. Interkostalraum rechts. (B) Ultraschall von KometenschweifArtefakten und einer kleinen ovalen, hypoechogenen Stelle im 10. Interkostalraum links. (C) Ultraschall der ventralen Lungengrenze im 10. Interkostalraum rechts mit unregelmäßiger Pleuraoberfläche und Kometenschweif-Artefakten 
lung lesions as well as further treatment. The mare was humanly destroyed.

\section{Pathology, histopathology and immunohistochemistry}

Necropsy revealed a poorly demarcated, non-encapsulated and invasively growing mass of approximately $10 \times 10 \times 15$ $\mathrm{cm}$ in size, dorsally in the musculature at the level of vertebra C4 (Figure 2A) infiltrating the vertebral body and the spinal canal (Figure 2B). The dark red mass was of soft and spongy texture containing multifocal firm, yellow strands of tissue and mineralized areas. Within the spinal canal the mass extended cranially up to the level of C1-C2 where it invaded the spinal cord. Multiple nodular, yellow to brown and firm masses of approximately 0.5 to $10 \mathrm{~cm}$ in diameter were present in all lung lobes (Figure 2D). Multiple nodules had a necrotic center and the masses often appeared to be located in vessels (Figure 2E).

Histologically, the masses within the musculature, vertebra, spinal cord and lung were infiltratively growing, poorly demarcated and non-encapsulated. They were composed of spindle cells arranged in strands forming multiple small blood filled clefts and caverns (Figure 2C). The neoplastic spindle cells were approximately 15 to $20 \mu \mathrm{m}$ in length, with a low to moderate amount of eosinophilic cytoplasm, ovoid hyperchromatic nuclei with 1 to 2 centrally located nucleoli. There was marked anisocytosis and anisocaryosis and a high mitotic activity ( $>3$ mitoses per $400 \times$ field). In the lung, many neoplastic nodules were located in vessels and surrounded by abundant well differentiated cell poor connective tissue (Figu- re $2 \mathrm{~F})$. The centers of large masses contained necrotic debris. Infiltrating neoplastic cells were associated with bone resorption in the vertebra and replaced large parts of the dorsal spinal cord white and grey matter at the level of C1-C2. Adjacent white matter showed axonal degeneration with axonal spheroids and axonophagia. Immunohistochemically, neoplastic spindle cells stained positive for the endothelial cell marker CD31.

Based on macroscopic, histological and immunohistochemical findings a diagnosis of hemangiosarcoma of the spindle cell type, with formation of multiple vascular channels, was made. Most likely the tumor arose within the musculature dorsal to the cervical spinal cord with invasion of underlying vertebra and spinal cord and hematogenous metastasis to the lungs.

\section{Discussion}

Space-occupying lesions, notably soft tissue neoplasias like hemangiosarcoma, are a rare cause of spinal ataxia in horses (van Biervliet et al. 2006). More common ones are trauma, stenotic or compressive myelopathy, infectious diseases like equine herpesvirus-1 myeloencephalopathy, verminous lesions and in young horses equine degenerative myeloencephalopathy (Seino et al. 2010). After exclusion of the above mentioned differentials, soft tissue neoplasia should be considered as a potential cause of spinal ataxia. Furthermore, additional clinical signs like respiratory compromise because of pulmonary metastasis as observed in the present case, may indicate multifocal or disseminated disease.



Fig. 2 Macroscopic and histologic features of the invasive hemangiosarcoma. (A) Primary neoplasm arising from the musculature of the neck (arrow), (B) invading cervical vertebra (right arrow) and spinal canal (left arrow). (C) Invasive neoplastic endothelial cells in vertebral bone forming blood filled lacunae (H\&E stain, magnification 400x). (D) Multiple nodular metastases in all lung lobes. (E) Cross section of lung with multiple metastases localized in vessels. (F) Neoplastic nodule with spindle cells forming blood filled spaces and surrounded by connective tissue (H\&E stain, magnification 400x).

Makroskopische und histologische Merkmale des invasiven Hämangiosarkoms. (A) Primärtumor, der von der Halsmuskultatur ausgeht (Pfeil) und (B) den Halswirbel (rechter Pfeil) und das Rückemark (linker Pfeil) infiltiert. (C) Invasive Tumorzellen bilden blutgefüllte Lakunen im Wirbelknochen (H\&E Färbung, Vergrösserung 400x). (D) Multiple noduläre Metastasen in allen Lungenlappen. (E) Querschnitt der Lunge mit multiplen Metastasen in Blutgefässen. (F) Neoplastischer Knoten mit Spindelzellen, die blutgefüllte, von Bindegewebe umschlossene Räume bilden (H\&E Färbung, Vergrößerung 400x). 
Neoplasia affecting the spinal cord and vertebral canal occurs rarely in horses and is located either extradurally, intradural extramedullary or intradural intramedullary. Extradural compression and intramedullary metastasis of non-neuronal origin are more common than primary neuronal tumors (van Biervliet et al. 2006). In this case, the mass was most likely extradural in origin arising in the paravertebral musculature and secondarily invading the vertebral body and spinal canal. This later resulted in intramedullary dissemination into the white and gray matter of the spinal cord.

Hemangiosarcomas are known to originate from a variety of tissues - including musculature and bone- and may even be multicentric in their origin. For this reason the site of the primary tumor remains speculative, in this case. Pulmonary lesions were considered to be metastases since characteristics typical of hematogenous spread, including tumor emboli in blood vessels with invasion into the surrounding tissue, were evident. It is presumed that these occurred prior to spinal cord invasion. This suspicion is supported by the fact that respiratory symptoms were observed two months before the acute onset of ataxia. Furthermore, the marked fibrosis observed around pulmonary metastases indicates chronicity of these lesions.

The most common metastatic tumor affecting the spinal cord in aged grey horses is melanoma (Schott et al. 1990, Rodriguez et al. 1998, Patterson-Kane et al. 2001). Further soft tissue neoplasms affecting the spinal cord in horses either by compression or infiltration are intestinal adenocarcinoma (Spoormakers et al. 201 1), undifferentiated sarcoma (van Bienvliet et al. 2004) and lymphosarcoma (Rousseaux et al. 1989, Hirsch et al. 2009, Ueno et al. 2012) and carry a poor prognosis.

Hemangiosarcoma causing spinal ataxia due to compression or infiltration of the spinal cord has only rarely been reported in horses and donkeys (Fatone et al. 1993, Kennedy and Brown 1993, Newton-Clarke et al. 1994, Lombardo de Barros 1997, Berry 1999, MacGillivray et al. 2003, Hirsch et al. 2009). In all seven case reports hemangiosarcoma were found either in the vertebrae or in the paravertebral musculature, but not in other body sites. In contrast, the Warmblood mare in the present case report showed signs of disseminated neoplastic disease with metastatic lesions in the lung.

In all previously reported cases of hemangiosarcoma affecting the spinal cord including the present a definitive ante mortem diagnosis was not reached. Radiographs and subsequent myelogram studies may reveal lytic vertebral lesions and evidence of spinal cord compression (Kennedy et al. 1993, Newton-Clarke et al. 1994, MacGillivray et al. 2003). Nevertheless, such radiographic findings may be also compatible with discospondylitis and vertebral body osteomyelitis and are therefore not specific for a neoplastic cause. Cerebrospinal fluid analysis has been performed in the present case. It helped to exclude septic or non-septic meningoencephalomyelitis as well as clinically relevant hemorrhage, but did not reveal a specific diagnosis of neoplasia. Even if tumors are located intradurally they do not necessarily exfoliate neoplastic cells into the cerebrospinal fluid. Further rather unspecific cerebrospinal fluid alterations in patients with neoplasia include increased creatinine kinase activities (Fatone ef al. 1993) and slight elevation in protein content (Spoormakers et al. 2001). Slightly increased protein content was detected with the Pandy reaction in the cerebrospinal fluid of this case. Definite ante mortem diagnosis of neoplasias affecting the spinal cord remains challenging since cerebrospinal fluid alterations are often unspecific and masses are difficult to access for biopsies or fine needle aspirates.

Hemangiosarcoma, an often very aggressive tumor of blood vessel origin with a high metastatic rate, is an uncommon equine neoplasm. It occurs mainly as a disseminated form with multiple organ involvement in mature, middle-aged horses. Equine hemangiosarcoma preferentially affects the musculoskeletal and respiratory system, but can occur in any location of the body. Common clinical signs comprise dyspnea, subcutaneous or muscular swellings, epistaxis and lameness (Southwood et al. 2000, Reischaver et al. 2006). In young horses, locally invasive forms with cutaneous and musculoskeletal involvement are more frequent and may even be congenital (Dunkel et al. 2004, Johns et al. 2005, Lempe et al. 2008). Affected horses present with cutaneous or leg swelling and joint effusion (Johns et al. 2005, Lempe et al. 2008). Benign and malignant cutaneous forms of hemangiosarcoma exist in the horse. Locally noninvasive cutaneous lesions are commonly benign and referred to as hemangioma or, if congenital, hamartoma (Johnstone 1987, Platt 1987, Southwood et al. 2000).

Equine hemangiosarcoma usually progresses rapidly, frequently metastasizes and in general carries a poor prognosis. Clinical deterioration may be rapid with a median time from onset of clinical signs to euthanasia of 17 days in a report on 35 cases with disseminated hemangiosarcoma (Southwood et al. 2000). More localized forms in younger horses may have a better outcome if surgical excision is possible. Treatment of localized hemangiosarcomas mainly consists of surgical resection, cryotherapy and topical 5-fluorouracil treatment. Nevertheless, multiple surgeries and extensive resection may be required (Johns et al. 2005). All published cases of equine vertebral hemangiosarcoma showed a negative outcome, all affected horses had to be subjected to euthanasia (Fatone et al. 1993, Kennedy et al. 1993, Newton-Clarke et al. 1994, Lombardo de Barros 1997, Berry 1999, MacGillivray et al. 2003, Hirsch et al. 2009). In one horse with epidural hemangiosarcoma causing malalignement at the level of C4-C5 a subtotal dorsal decompression was attempted and failed (Hirsch et al. 2009).

In conclusion, a soft tissue neoplasm affecting the spinal cord like hemangiosarcoma in the present case should be considered in horses with rapidly progressing spinal ataxia of unknown origin. Further clinical signs like respiratory symptoms may indicate metastasis to distant sites. An ante mortem diagnosis is difficult to reach and the prognosis is particularly poor.

\section{References}

Andrews F. M. (2010) Cerebrospinal fluid evaluation. Equine Internal Medicine. 3rd edition, editors: Reed S. M., Bayly W. M., Sellon D. C., W.B. Saunders, Philadelphia, 553-556

Berry S. (1999) Spinal cord compression secondary to hemangiosarcoma in a saddlebred stallion. Can. Vet. J. 40, 886-887

Dunkel B. M., Del Piero F., Kraus B. M., Palmer J. E., Lin P. and Wilkins P. A. (2004) Congenital cutaneous, oral and periarticular hemangiosarcoma in a 9-day-old Rocky Mountain Horse. J. Vet. Intern. Med. 18, 252-255 
Fatone S., Edens L. and McElhaney B. (1993) Challenging cases in internal medicine: what's your diagnosis? Vet. Med. 88, 1039-1044

Hirsch J. E., Grant B. D., Linovitz R., Peppers T. A. and Rantanen N. $W$. (2009) Diagnosis and surgical treatment of epidural neoplasms in two ataxic horses. Equine Vet. Educ. 21, 564-568

Johns I., Stephen J. O., Del Piero F., Richardson D. W. and Wilkins P. A. (2005) Hemangiosarcoma in 11 young horses. J. Vet. Intern. Med. 19, 564-570

Johnstone A. C. (1987) Congenital vascular tumors in the skin of horses. J. Comp. Path. 97, 365-368

Kennedy F. A. and Brown C. M. (1993) Vertebral angiosarcoma in a horse. J. Vet. Diagn. Invest. 5, 125-127

Lempe A., Ludewig E., Reischaver A. and Scharner D. (2008) Erfolgreiche operative Entfernung eines Hämangiosarkoms bei einem Fohlen. Pferdeheilkunde 24, 680-687

Lombardo de Barros C. S. (1997) Vertebral hemangiosarcoma as a cause of spinal cord compression in a horse. Ciência Rural 27, 503-504

MacGillivray K. C., Sweeney C. R., McLear R. and Habecker P. L. (2003) Vertebral body hemangiosarcoma in a 16-year-old miniature Sicilian donkey. Vet. Radiol. Ultrasound 44, 429-432

Newton-Clarke M. J., Guffoy M. R. G., Dykes N. L. and Divers T. J. (1994) Ataxia due to a vertebral hemangiosarcoma in a horse. Vet. Rec. 135, 182-184

Patterson-Kane J. C., Sanchez L. C., Uhl E. W. and Edens L. M. (2001) Disseminated metastatic intramedullary melanoma in an aged grey horse. J. Comp. Path. 125, 204-207

Platt H. (1987) Vascular malformations and angiomatous lesions in horses: A review of 10 cases. Equine Vet. J. 19, 500-504

Reischaver A., Grosche A., Gieseler T., Jäger K., Huth H. and Schoon H.-A. (2006) Chronische Blutungsanämie bei zwei Pferden mit Hämangiosarkom. Pferdeheilkunde 22, 131-139

Rodriguez F., Forga J., Herraez P., Andrada M. and Fernandez A. (1998) Metastatic melanoma causing spinal cord compression in a horse. Vet. Rec. 142, 248-249

Rousseaux C. G., Doige C. E. and Tuddenham T. J. (1989) Epidural lymphosarcoma with myelomalacia in a seven-year-old Arabian gelding. Can. Vet. J. 30, 751-753

Schott H. C., Major M. D., Grant B. D. and Bayly W. M. (1990) Melanoma as a cause of spinal cord compression in two horses. J. Am. Vet. Med. Assoc. 196, 1820-1822

Seino K. K. (2010) Spinal ataxia. Equine Internal Medicine. 3rd edition, editors: Reed S. M., Bayly W. M., Sellon D. C., W.B. Saunders, Philadelphia, 553-556

Southwood L. L., Schoett H. C., Henry C. J., Kennedy F. A., Hines M. T., Geor R. J. and Hassel D. M. (2000) Disseminated hemangiosarcoma in the horse: 35 cases. J. Vet. Intern. Med. 14, 105-109

Spoormakers T. J. P., lizer J. and Sloet van Oldruitenborgh-Oosterbaan M. M. (2001) Neurological signs in a horse due to metastases of an intestinal adenocarcinoma. Vet. Quart. 23, 49-50

Ueno T., Wada S., Mashita S., Kuwano A. and Katayama Y. (2012) Pathological findings in a case of equine T-cell lymphoma associated with ataxia. J. Equine Vet. Sci. 32, 315-319

Van Biervliet J., Alcaraz A., Jackson C. A., Niaa B., De Lahunta A. and Divers T. J. (2004) Extradural undifferentiated sarcoma causing spinal cord compression in 2 horses. J. Vet. Intern. Med. 18, 248-251

Van Biervliet J., De Lahunta A. and Divers T. J. (2006) Sporadic conditions affecting the spinal cord: parasitic migration and neoplastic disease. Clin. Tech. Equine Pract. 5, 49-53

Dr. Lucia Unger

Institut Suisse de Médecine Equine ISME

Universität Bern und ALP-Haras, Avenches

Länggassstrasse 124

3012 Bern

Schweiz

lucia.unger@vetsuisse.unibe.ch 